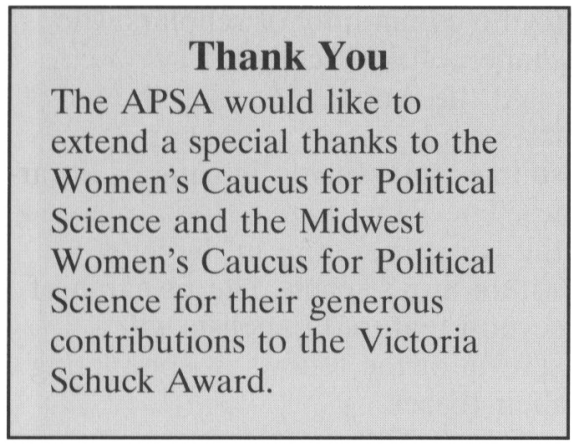

search for information in surrounding areas. Without neglecting sightseeing opportunities like Chinatown and the Golden Gate Bridge, they visited Stanford University and the University of California at Berkeley. At least two of the fellows intend to apply to these institutions for graduate study.

With all of these activities, the APSA Annual Meeting provided the ideal capstone to the five weeks of study at the University of Virginia. The fellows attending were: AnnMarie Beckford, Long Island University-Brooklyn Campus; Heather Dash, University of Washington; Jason Johnson, University of Virginia; Herlande Rosemond, Bowdoin College; Derrick Sanders, Lincoln University; and Tharius Sumter, Oglethorpe University.

\section{APSA Council Actions}

The APSA Council Meeting was held on August 28, 1996, at the San Francisco Hilton \& Towers. A wide range of issues was discussed and a number of actions were taken at this Council meeting. The followings are the highlights of this Council Meeting.

Responding to a letter from Ben Marquez on behalf of the Committee on the Status of Latinos in the Profession, the Council decided to increase the number of Latino Fellowships from one to two and will regularly review the minority fellowships as circumstances are likely to change in the current legal environment.

Recognizing the extensive contributions of Walter E. Beach to APSA, the National Capital Area Political Science Association, the Southern Political Science Associa- tion, and the Women's Caucus, the Council named the APSA's archive at Mount Vernon College as Walter E. Beach Archive.

In order to broaden existing language about the employment issue and incorporate explicit statements about discrimination on the basis of sexual orientation with respect to all aspects of employment, the Council approved the recommendation of the Committee on Professional Ethics, Rights, and Freedoms that Section F of the APSA's Ethics Guide be retitled as "Personnel Issues" generally and the old language which referred exclusively to hiring practices be altered to refer to "any conditions of employment" (with "against job candidates" struck and "in any condition of employment" added).

Elinor Ostrom's proposal to create a Task Force of the American Political Science Association on Civic Education for the New Century was approved by the Council.

The three core strategies and materials for the Centennial Campaign including the Campaign Statement, the establishment of the Goodnow Award, and an endowment spending rate of $5 \%$ were approved, as were APSA's alliance with H-Net, its revised budget for FY96-97, and the allocation of $\$ 30,000$ of the FYI 1996 budget surplus to the Ralph Bunche Summer Institute with the remaining amount of the surplus to the Second Century Fund.

In addition, the Council approved the increased program committee budget (from $\$ 5,000$ to $\$ 12,500$ ), the centralization of proposals process, and a proposed non-refund policy of preregistration fee for the 1997 Annual Meeting.

\section{Member Contributions Boost Dissertation Award Endowments}

At the last Council Meeting on August 28, 1996, Sheilah Mann gave an update on APSA's fund raising for dissertation awards. She reported that among the four dissertation awards which did not have the required endowment (\$500 cash prize) in 1995, the Corwin Award, the Almond Award, and the Anderson award had now met the requirement - thanks to the special efforts and contributions of Sam Krislov, Arend Lijphart, and Walter E. Beach. The endowment for the E.E. Schattschneider Award is still some $\$ 1,900$ less than the requirement, although significant progress had been made since 1995. The campaign for the contributions to the Schattschneider endowment will continue in order to meet the requirement in 1997. Individuals interested in making a contribution should contact Sheilah Mann at the APSA National office.

\section{First Higher Education Advisory Group Meeting Held at Annual Meeting}

APSA's Higher Education Advisory Group met for the first time on August 29th at the Annual Meeting in San Francisco. The group consists of political scientists with major administrative posts in higher education who were invited by APSA to meet to discuss a wide range of issues affecting political science and higher education today. The group agreed it should have three principal roles: to work together as a professional support group, to encourage the study of the politics of higher education, and to advise and help APSA with lobbying efforts at the state and federal levels.

A wide range of issues was discussed, and the group stressed the need to increase political scientists' awareness of trends in higher education. Among the topics addressed were the state of the tenure system, strains in student financial aid, and continued APSA participation in the fight to stop funding cuts to the $\mathrm{Na}$ tional Science Foundation and the National Endowment for the Humanities.

\section{Discussion Groups Held in San Francisco}

APSA conducted four discussion groups at the 1996 Annual Meeting to hear members' views of the Association's services and programs and their outlook on the future of the profession and discipline. 
Facilitated by Wendy Child of Campbell Communications, each group brought together 10-15 association members and focused on the kinds of initiatives needed to support political scientists in the next century.

Each group expressed concern about the growing need for assistance to graduate students and faculty at less endowed institutions. Participants also called for continued APSA participation in the fight against cuts to education funding.

Campbell Communications' report on the discussion groups will be used to direct APSA's resources where they are most needed and develop goals and strategies for the association's Centennial Campaign.

\section{Political Science Chairs Recommend Strategies to Counter Decreases in Undergraduate Enrollments}

A session devoted to exploring sources of and responses to declining undergraduate political science course enrollments was held on August 28 during the Conference for Chairs at the APSA Annual Meeting in San Francisco. The session provided department chairs with data collected by the Association in its annual survey of departments. It also gave chairs the opportunity to exchange ideas on how to attract students to political science courses and encourage them to major in the discipline.

Gary Klass, who initiated the discussion of enrollment trends on the PSRT-L last spring, distributed data on enrollments in Illinois. For the APSA, Sheilah Mann provided updated and enlarged graphs tracking decreases in undergraduate enrollments and majors for the categories of departments represented in the Association's Annual Surveys. These data were presented in full in the last issue of PS: Political Science \& Politics (Mann 1996).

The 91 participants at the session concurred that decreasing student interest in political science is widespread. The possible causes of this development, also identified in the September PS: Political Science \&
Politics, were reviewed. Several department chairs emphasized declining interest in public affairs, disillusionment with politics, and the denigration of public service as factors taking a toll on the discipline's appeal. Some participants recommended that the profession respond by raising the level of discourse about politics and government, and by attempting to counter negative public perceptions of politics and politicians.

Some participants argued that political science departments should assert the importance of their courses for teacher preparation, and even consider designing courses specifically for training pre-college teachers. The U.S. Department of Education has released figures projecting growth in school enrollments, with a predicted increase of $15 \%$ in high school enrollments by 2006 . The expansion of the student population is expected to be matched by a $16 \%$ growth in the number of high school teachers. Regional variations in school enrollment growth are projected as well: $21 \%$ in the West, $10 \%$ in the South, $4 \%$ in the Northeast and 3\% in the Midwest (1996, U.S. Department of Education).

Participating chairs offered additional suggestions about introductory courses for non-majors. One example is a course in world politics designed to prepare students to be continually informed about international events and developments. There was a consensus that the introductory courses in the discipline are especially important and should be given more attention. These are the courses that introduce political science to students, provide needed instruction about government and public affairs to students in pre-professional programs such as business, journalism, engineering, and education, and also serve to recruit majors. Some departments reported making a special effort to provide smaller-sized sections in these courses and assigning them to effective teachers. Some departments also reported inviting the students who do well in the introductory courses to major in political science.

Peter Zwick, California State University at San Marcos advised departments to learn what interests students and then respond to such interests. His comment was followed with observations that students and their parents are especially concerned about employment prospects, and departments must therefore provide instructional formats such as internships, and simulations of organizations like the model U.N. and model state legislature programs. Ron Peters, University of Oklahoma, reported that his department offers a one-credit course on careers in political science.

Lyman Sargent noted that his department at the University of Missouri, St. Louis introduced several strategies to appeal to students, but still experienced enrollment declines. Participants agree that further examination is still needed to uncover the sources of the decline, including the examination of departments not recording lower undergraduate enrollments or fewer majors.

The Association will try to collect this information in the coming year and invites departments to submit descriptions of programs and courses that attract students and meet special needs.

\section{Committee Suggestions Welcomed}

The APSA welcomes suggestions for individuals interested in serving on APSA Standing Committees for terms beginning in January 1, 1998. These appointments vary from one to three years and include award committees, PS Editorial Board, and a host of others. A listing of committees and their area of responsibility can be found in the March 1996 issue of PS. These positions are held on a volunteer basis. Interested members should make their suggestions by mail, to PresidentElect M. Kent Jennings, c/o the National Office at 1527 New Hampshire Ave., NW, Washington, DC 20036 or e-mail at rudder@apsa.com. 